\title{
Observational study on the breeding performance of emus (Dromaius novaehollandiae) in Brazil
}

\author{
[Estudo observacional sobre o desempenho reprodutivo de emus \\ (Dromaius novaehollandiae) no Brasil] \\ J.C.P. Quintero ${ }^{1}$, L.F.L. Calixto ${ }^{1}$, A.J. Almeida ${ }^{2}$, Y.R. Moreira ${ }^{2}$, \\ S.S. Rocha ${ }^{2}$, K.A.A. Torres-Cordido ${ }^{2 *}$ \\ ${ }^{1}$ Instituto de Zootecnia - Universidade Federal Rural do Rio de Janeiro - Seropédica, RJ \\ ${ }^{2}$ Centro de Ciências e Tecnologias Agropecuárias - Universidade Estadual do \\ Norte Fluminense Darcy Ribeiro - Campos dos Goytacazes, RJ
}

\begin{abstract}
The objective of this study was to describe emus' breeding performance in Brazil at different ages, grouped in couples or colonies. The duration of the breeding season and the production of eggs per female housed were recorded, and the productivity and breeding variables were associated with the variation of the photoperiod. The total production of the flock was $180 \mathrm{eggs}$, and the breeding season lasted 167 days (AprilSeptember), a period with an average of $11 \mathrm{~h}$ and $11 \mathrm{~min}$ of daylight. The breeding season lasted 113, 133 and 82 days, the numbers of eggs produced per female were 7.29,25.67 and 17.3, and productivity values were $31.6,38.6$, and $45.4 \%$ in the groups of birds with ages of two, four and seven years, respectively. The breeding season in 2016 occurred between April and August in Brazil. Older birds tended to start breeding later. The production rate observations indicated that earlier peak production was associated with lower egg production potential. Finally, there was a tendency for better breeding performance of birds housed in couples than in groups with more birds.
\end{abstract}

Keywords: exotic birds, Dromaius novaehollandiae, breeding season, egg production, ratites

\section{RESUMO}

O objetivo deste estudo foi descrever o desempenho reprodutivo de emus de diferentes idades, agrupados em casais ou em colônias, no Brasil. A duração da estação reprodutiva e a produção de ovos por fêmea alojada foram registradas, a produtividade e as variáveis reprodutivas foram associadas às variações no fotoperíodo. A produção total do lote de aves foi de 180 ovos, e a estação reprodutiva durou 167 dias (abril-setembro), período que apresentou fotoperiodo médio de 11 horas e 11 minutos. Nos grupos de aves de dois, quatro e sete anos de idade, a estação reprodutiva durou 113, 133 e 82 dias, o número de ovos por fêmea foi de 7,29, 25,67 e 17,3 e a produtividade foi de 31,6, 38,6 e 45,4\%, respectivamente. A estação reprodutiva em 2016 ocorreu entre abril e agosto no Brasil. Aves mais velhas tenderam a iniciar o período reprodutivo mais tarde. As observações na taxa de produção podem indicar que quanto mais precoce o pico produtivo, menor o potencial de produção de ovos em emus. Houve a tendência ao melhor desempenho reprodutivo das aves alojadas em casais em comparação com as alojadas em colônias.

Palavras-chave: aves exóticas, Dromaius novaehollandiae, estação reprodutiva, produção de ovos, ratitas

\section{INTRODUCTION}

The emu (Dromaius novaehollandiae), a ratites species of Australian origin, is the second biggest bird in the world. The reproductive data of captive emus come from countries where the emu is commercially raised, such as Australia, India, United States, and Canada (Malecki and Martins, 2002; Dzialowski and Sotherland, 2004; Goonewardene et al., 2003; Senthilkumar et al.,

Recebido em 14 de maio de 2020

Aceito em 18 de agosto de 2020

*Autor para correspondência (corresponding author)

E-mail: karoll@uenf.br 
2014). Emu farming produces high revenues, especially in the USA and Australia, due to the high value of products like skin (leather), feathers, eggs, meat and refined emu oil, sold to the pharmaceutical industry (AgMRC, 2018; Safaeian et al., 2019).

Emu reproduction is related to factors like age, housing conditions, group hierarchy, climate conditions, nutrition and genetics (Szczerbińska et al., 2014). Sexual maturity typically occurs between two and three years old, but birds in captivity can breed at younger ages (Patodkar et $a l ., 2009)$. The egg production is seasonal, since emus are photosensitive, where a decrease of sunlight hours stimulates the start of reproduction (Blache et al., 2001). Females in captivity lay one egg every three or four days and produce more than 20 eggs per season (Sales, 2007). Studies have demonstrated that the egg production peaks between the fourth (Senthilkumar et al., 2014) and fifth breeding season (Szczerbińska et al., 2014), and declines after that. Therefore, they recommended not using females more than seven years old for captive breeding.

To the best of our knowledge, there are no data in the scientific literature describing the breeding performance of captive emus in Brazil. The observation of variables such as breeding season, duration of laying, average production of eggs per female and egg productivity is relevant to expand knowledge about the reproductive traits of this species under Brazilian climate and geographic conditions. This information is necessary to support planning of emu farms, both for ongoing concerns and new projects, and serves as a base to plan research because the results can differ according to the geographic area. Therefore, this study describes observations of the reproductive performance of emus (Dromaius novaehollandiae) of different ages raised in groups of couples or colonies in the city of Campos dos Goytacazes, Rio de Janeiro state, Brazil, during the 2016 breeding season.

\section{MATERIAL AND METHODS}

The study was conducted at Darcy Ribeiro North Fluminense State University (UENF) and was approved by the Ethics Committee on Animal Use of UENF (Protocol No. 346, 2016). The study was observational, carried out between February and October 2016, at the Rhea and Emu Scientific Hatchery at the Center for Agricultural Sciences and Technologies of UENF, located in Campos dos Goytacazes $\left(21^{\circ} 45^{\prime} 23^{\prime \prime}\right.$ South Latitude, $41^{\circ} 19^{\prime} 40^{\prime \prime}$ West Longitude and $14 \mathrm{~m}$ above sea level). The average weekly hours of daylight (photoperiod) was calculated using the records of sunrise and sunset, available at timeanddate.com ${ }^{\circledR}$. The breeding sector of the hatchery was divided into nine paddocks, with a height of $1.8 \mathrm{~m}$, and a covered area of approximately $9 \mathrm{~m}^{2}$. The rest of the area had a Guinea grass (Megathyrsus maximus) plant cover.

Twenty-four emus were used in the study, 11 males and 13 females. In February, the birds were separated into three different paddocks according to age: 2 years \pm 2 months, 4 years \pm 2 months, and 7 years \pm 2 months. However, during observation of the birds' behavior in the adaptation period in February, there was rejection by the other birds of a 2-year-old female and a 7-year-old female. Therefore, these birds were separated and housed with male birds of the same age to form couples. Thus, five reproductive groups (RG) were formed, as described in Table 1.

Table 1. Emu reproductive groups from a hatchery in Campos dos Goytacazes, Brazil

\begin{tabular}{lcccc}
\multicolumn{1}{c}{ Reproductive group } & Age (years) & Type of group & $\begin{array}{c}\text { Ratio } \\
\text { Male:Female }\end{array}$ & $\begin{array}{c}\text { Density } \\
\left(\mathrm{m}^{2} / \mathrm{bird}\right)\end{array}$ \\
\hline GR-1 & 2 & Colony & $6: 5$ & 55.8 \\
GR-2 & 2 & Couple & $1: 1$ & 74.4 \\
GR-3 & 4 & Colony & $3: 2$ & 127.7 \\
GR-4 & 7 & Colony & $2: 2$ & 52.5 \\
GR-5 & 7 & Couple & $1: 1$ & 107.9 \\
\hline
\end{tabular}

Water and feed were supplied ad libitum. The feed was formulated based on cornmeal, soybean bran, and wheat bran, with $2,658 \mathrm{kcal} \mathrm{kg}^{-1}$ of metabolizable energy and $170.6 \mathrm{~g} \mathrm{~kg}^{-1}$ of crude protein (Scheideler and Sell, 1997; Rostagno et al., 2011). The performance data were obtained through surveillance of the paddocks between February 1 and October 31. Behavior was 
monitored daily to identify signs indicating the beginning of production, such as female receptivity, vocalization, more intense blue coloration of the neck skin, increase of the male feather volume, building of nests by males and egg-laying. The paddocks and nests were both inspected for the presence of eggs. In this way, it was possible to register the dates of the first and the last egg laid, that is the beginning (Start) and the end (End) of the breeding season.

The cumulative percentage of egg production of the flock and each reproductive group was calculated. The dates that corresponded to the p $10 \%$ and $\mathrm{p} 90 \%$ percentiles of production of the flock delimited the period in the season with higher egg production. The egg production per female (EPF) of each reproductive group and the entire flock were calculated by dividing the total number of eggs produced in the season by the total number of females in the respective group. Also, the EPF per day was calculated.

The productivity (PO) in each reproductive group was calculated by

$P O(\%)=\frac{\text { average of eggs per female }}{\text { duration of the breeding season } \times 0.5} \times 100($ Van

Schalkwyk et al., 1996).

To study the EPF rate, the cumulative EPF data were analyzed by the software CurveExpert 1.4 to obtain the fit of sigmoidal logistic models and their parameters: $a, b$ and $c, y=\frac{a}{1+b * e(-c x)}$, where $a$ represents the maximum achievable value of $y$ (Cordido, 2019). The intersection point between the two concavities of the sigmoidal curve (P2) was also obtained, using the second derivative of the model, $\frac{d^{2} y}{d x^{2}}=\frac{-1}{c} \times \ln \frac{1}{b} . \mathrm{P} 2$ represented the moment when the productive peak occurred (Cordido, 2019).

\section{RESULTS AND DISCUSSION}

Table 2 summarizes the breeding performance of emus in the 2016 breeding season, indicating the start, end and duration of the season, besides the egg production per female and productivity. Figure 1 illustrates the beginning and end of egg production of every reproductive group, expressing the production in cumulative percentage throughout the period. The figure also depicts differences in the duration of the season among the groups.

Comparison of the reproductive groups with same ages indicated that the youngest colonies began production earlier than the oldest colonies, and the youngest couple began production earlier than the oldest couple (Table 2 and Figure 1). This behavior regarding ages was like that observed in an emu hatchery in Szczecin, Poland, (Szczerbińska et al., 2014). The grouping in couples or colonies influenced the beginning of the season. In groups formed of couples, the beginning of laying was later than in birds living in colonies of the same age. However, in this case the delay at the start of laying was due to the possible stress caused by the rejection of the female by the reproductive group and by the exchange of paddocks.

Table 2. Breeding performance of the reproductive groups in Campos dos Goytacazes, RJ, Brazil

\begin{tabular}{cccccccc}
\hline \multirow{2}{*}{ RG } & \multirow{2}{*}{$\begin{array}{c}\text { Age } \\
\text { (years) }\end{array}$} & $\begin{array}{c}\text { Type of } \\
\text { Group }\end{array}$ & \multicolumn{3}{c}{ Breeding season } & \multirow{2}{*}{ EPF } & \multirow{2}{*}{ PO $(\%)$} \\
\hline RG 1 & 2 & Colony & $15 / 04$ & End (date) & Duration (days) & & \\
RG 2 & 2 & Couple & $20 / 05$ & $06 / 08$ & 113 & 6 & 10.6 \\
RG 3 & 4 & Colony & $19 / 05$ & $29 / 07$ & 57 & 15 & 52.6 \\
RG 4 & 7 & Colony & $20 / 05$ & $10 / 08$ & 133 & 25.7 & 38.6 \\
RG 5 & 7 & Couple & $26 / 05$ & $07 / 08$ & 72 & 17 & 41.5 \\
Flock & & & $15 / 04$ & $29 / 09$ & 167 & 18 & 49.3 \\
& & & & & & &
\end{tabular}

RG: Reproductive group; EPF: Egg production per female; $\mathrm{PO}(\%)$ : productivity. 


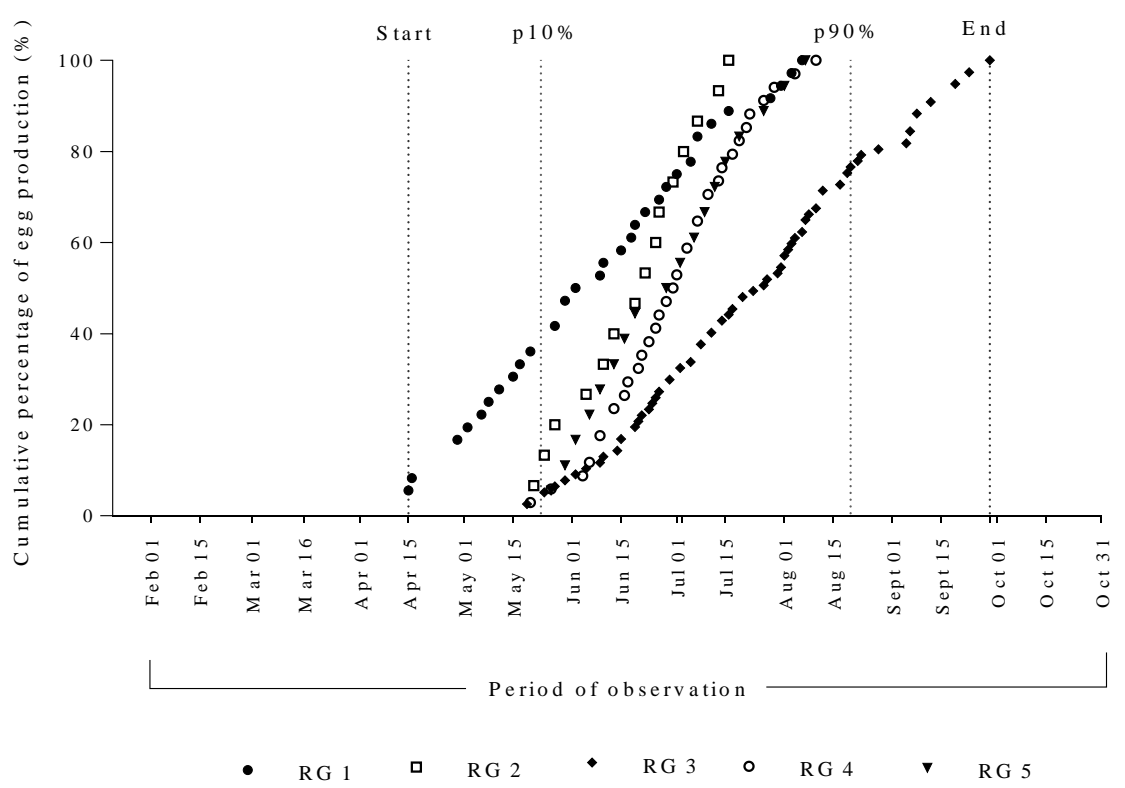

Figure 1. Cumulative percentage of egg production (\%) throughout the 2016 breeding season of emus of different ages raised in Brazil; RG: reproductive group (check Table 1); p10\%: 10th percentile; p90\%: 90th percentile.

Regarding the photoperiod, from January 1st to April 15th (start of the breeding season), the average daylight period was $12 \mathrm{~h}$ and $43 \mathrm{~min}$. Between April 15th and September 29th (start and end of the season), the average daylight period decreased to $11 \mathrm{~h}$ and $11 \mathrm{~min}$, and between September 29th and December 31st, the average daylight increased to $13 \mathrm{~h}$ and 30min. Eighty percent of the flock's egg production was concentrated between May 23rd and August 20th (p10\% to p90\% of production), when the shortest photoperiod observed during the breeding season occurred, of $10 \mathrm{~h}$ and $56 \mathrm{~min}$ (Figure 1 and 2). Malecki and Martins (2002) reported that emus in captivity in Western Australia $\left(31^{\circ} 57^{\prime} 8^{\prime \prime} \mathrm{S}\right)$ laid more eggs in the same period.



Figure 2. Variation of the photoperiod in 2016 (Time and Date AS, 2018) related to the breeding season of emus raised in captivity in Brazil. 
Between April 15th and May 26th, 2016 (beginning period of all reproductive groups), the sunlight lasted for $1 \mathrm{~h}$ and $25 \mathrm{~min}$ less than in the previous period (January to April). On the other hand, the end of the breeding season was influenced by the increase of daylight by $2 \mathrm{~h}$ and 19min between September and December 2016, in comparison to the breeding period.

In emus living freely in Australia $\left(33^{\circ} 52^{\prime} 0^{\prime \prime} \mathrm{S}\right)$, the beginning of the breeding season was registered, in a similar period, between April and June (Patodkar et al., 2009). The determination of the beginning and end of the breeding season of emus based on research developed in other countries or areas is difficult, due to differences in the photoperiod related to latitude. The hormonal regulation of the reproductive period of emus is under the influence of photoperiod and longitude changes, as happens in other birds. Emus are typically reproductive on shorter days because of the decreased sunlight duration stimulates the beginning of reproduction (Blache et al., 2001).

The breeding season in other ratite species is also influenced by latitude. Ostriches raised in captivity in Turkey $\left(40^{\circ} 11^{\prime} 0^{\prime \prime} \mathrm{N}\right)$ presented breeding seasons between February and September (Ipek and Sahan, 2004). In the state of Minas Gerais $\left(18^{\circ} 33^{\prime} 0^{\prime \prime} \mathrm{S}\right)$, Brazil, the ostrich breeding seasons happen between June and January (Poblete et al., 2013). Rheas raised in captivity in Córdoba ( $\left.31^{\circ} 25^{\prime} 0^{\prime \prime} \mathrm{S}\right)$ in Argentina had a breeding season from September and January (Labaque et al., 2010).

The duration of breeding (DB) of the flock was 167 days, but there were variations among reproductive groups. The longest one was observed in a 4-year-old bird living in colonies (133 days), and the shortest (57 days) was in a 2year-old couple. The couples had shorter DB than colonies, and all were shorter than those reported in similar studies (Senthilkumar et al., 2014; Szczerbińska et al., 2014).

Therefore, the average DB of 2016 in the hatchery in Campos dos Goytacazes was short, and the reproductive period was delimited by the short photoperiod in the municipality.
The DB may vary depending on other factors, such as nutrition, housing conditions, group hierarchy, and climate conditions (temperature and precipitation) (Szczerbińska et al., 2014). The DB does not define the number of eggs produced. In other words, the longest DB is not necessarily related directly to higher production of eggs per bird (Senthilkumar et al., 2014), because other factors may be involved, like the housing in couples or colonies. This factor was better explained in this study by the productivity (Table 2 ), because the emus housed as couples produced more eggs per female than the emus raised in colonies, and it was not dependent on age. Figure 3 shows the rate of cumulative EPF in the breeding season and Table 3 shows the estimates of the parameters of the models and the P2 values.

We observed higher average egg production per female (EPF) by 4-year-old birds than that by 2and 7-year-old birds (Table 2), as also indicated the parameter $a$ of the models (Table 3). These results corroborate the observations of Szczerbińska et al. (2014) and Senthilkumar et al. (2014) about production changes related to age progression. The fit of logistic sigmoidal models to the cumulative EPF rates as a function of time, throughout the reproductive season, presented high correlation coefficients (Figure 3 and Table 3). The P2 of the flock happened on the 79th day (July 1st) after the start of the breeding season and indicated the moment of peak production, which occurred just after the shortest recorded day (Figure 2).

The EPF rate patterns differed between groups. The two-year-old colony of emus (RG 1) showed the lowest production rate, with a curve tending to horizontality. GR 1 also shown the earliest P2, and the parameter $a$ (which indicates productive potential) was the lowest compared to the other groups (Table 3). Then, there was the P2 of the two-year-old couple (RG 2), with a 13-day difference, but the productive potential doubled compared to RG 1. Next, there was the P2 of the GR 5 and 4, a colony, and a couple of seven-yearold birds, respectively. 

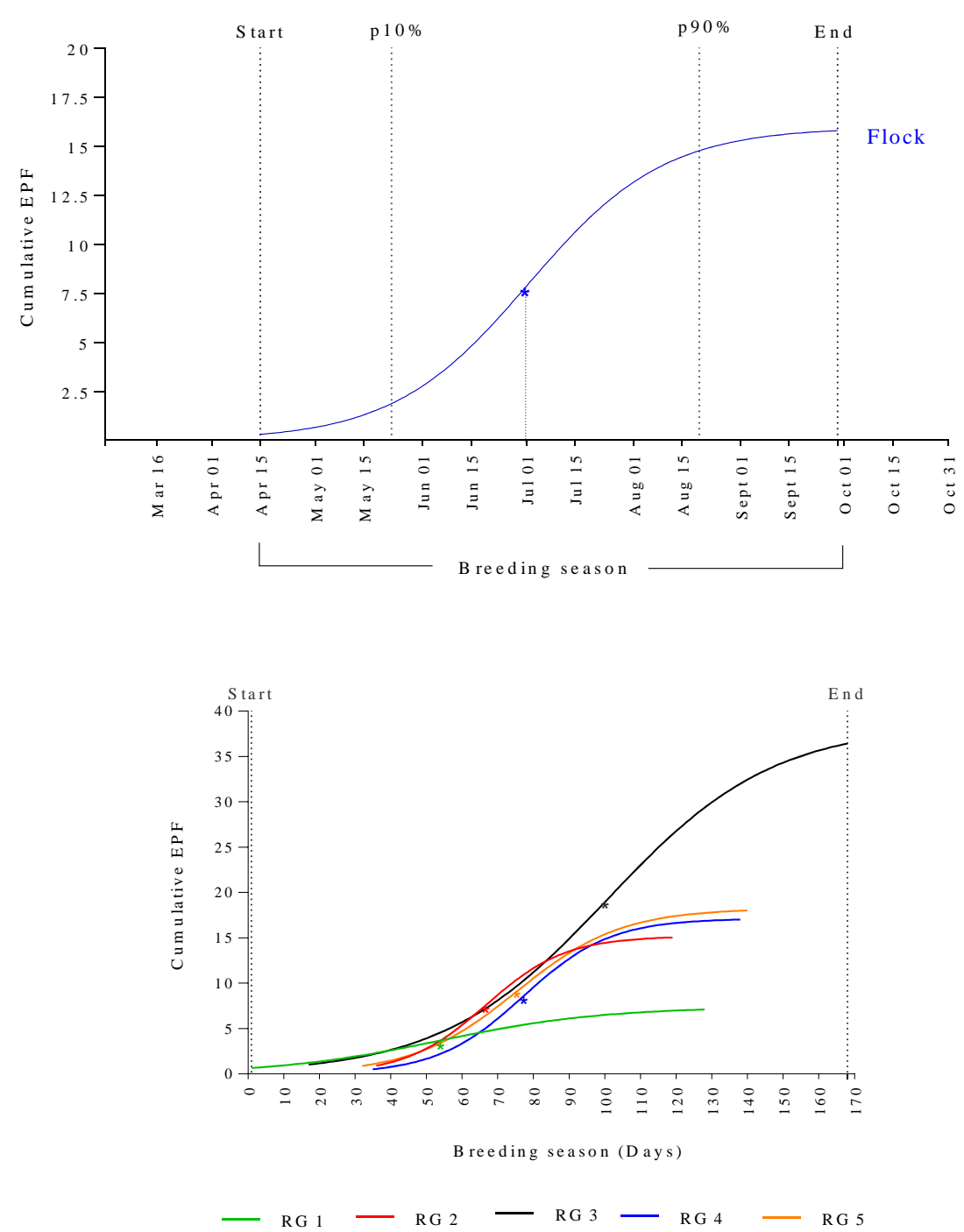

Figure 3. Egg production per female (EPF) rate curves, and P2 (*) of the flock (a) and the reproductive groups (b), throughout the breeding season of 2016, of emus of different ages raised in Brazil.

Table 3. Estimates of the parameters of the models fitted to the EPF rate as a function of the breeding season of the emus

\begin{tabular}{|c|c|c|c|c|c|}
\hline \multirow{2}{*}{$\begin{array}{l}\text { Reproductive } \\
\text { groups }\end{array}$} & \multicolumn{3}{|c|}{ Parameters of themodel $^{1}$} & \multirow[b]{2}{*}{$r^{2}$} & \multirow{2}{*}{$\begin{array}{l}\text { P2 } \\
\text { Days after starting the } \\
\text { breeding season (date) }\end{array}$} \\
\hline & $a$ & $b$ & $c$ & & \\
\hline RG 1 & 7.378410 & 10.532664 & 0.043618 & 0.995 & 54 (Jun 07) \\
\hline RG 2 & 15.181000 & 397.129768 & 0.089745 & 0.996 & 67 (Jun 20) \\
\hline RG 3 & 38.452667 & 75.506277 & 0.042943 & 0.995 & 101 (Jul 24) \\
\hline RG 4 & 17.134666 & 573.270445 & 0.082276 & 0.999 & 77 (Jun 30) \\
\hline RG 5 & 18.238003 & 175.903291 & 0.068544 & 0.994 & 75 (Jun 28) \\
\hline Flock & 15.954845 & 54.752278 & 0.050939 & 0.999 & 79 (Jul 02) \\
\hline
\end{tabular}

${ }^{1} y=\frac{a}{1+b * e}(-c x)$. P2: The intersection point between the two concavities of the sigmoidal curve. 
A 4-year-old colony (GR 3) had P2 later, during the increasing photoperiod, and had the highest productive potential $(\mathrm{a}=38.45)$, which was 2.4 times greater than that of the flock. These observations may indicate that the earlier the P2 (or peak production) was, the lower the potential for egg production by emus was. The greater productive potential observed in four-year-old emus compared to other ages, corroborates the results of Senthilkumar et al. (2014) and Szczerbińska et al. (2014). To validate those preliminary observations on the rate of egg production in emus, experimental studies are required.

Female emus can begin egg production at 2 or 3 years of age (Sales, 2007; Patodkar et al., 2009). In the present study, it was not possible to confirm whether all 2-year-old females in the colony (RG 1) began egg production in the mentioned breeding season, given that the low value of egg production per female of RG 1 may have been underestimated. The higher EPF registered by the couples ( 2 and 7 years old) in comparison with the colonies of the same age could be explained based on the social behavior observed of free-living emus, which are typically lone birds with poor sociability, given that during the breeding season the females show dominance over the males (Patodkar et al., 2009), a fact that could cause problems in the hierarchy of colonies, affecting egg production.

This different behavior among the reproductive groups of emus raised by couples or colonies is also evident when comparing the reports of Senthilkumar et al. (2014) and Szczerbińska et al. (2014). Finally, the productivity (PO) did not present the same pattern of change among ages as was observed in the EPF rate, and it seemed to have a stronger influence on the reproductive group's conformation type than on the birds' age. The 2-year-old emu couple registered the highest productivity (52.6\%), while the bird colonies of the same age registered the lowest productivity $(10.6 \%)$. The 7-year-old couple also presented higher productivity $(49.3 \%)$ than the colony of the same age $(41.5 \%)$.

The 4-year-old colony of birds had intermediate productivity (38.6\%) compared to other reproductive groups (Table 2). Therefore, the results in this study showed that couples had higher PO than colonies, irrespective of age, in line with the findings of Szczerbińska et al. (2014) in emu colonies compared with the PO results of emu couples presented by Senthilkumar et al. (2014). The PO is the proportion of EPF during the breeding season, and as previously outlined, the birds housed as couples presented the shortest breeding season and highest EPF, despite their ages.

The results of this study show that the breeding performance of emus raised in captivity in Campos dos Goytacazes in 2016 was seasonal, with the breeding season lasting 167 days, beginning between April and May, a period characterized by reduction of the photoperiod. Most of the egg production in the hatchery occurred in the months that had the shortest photoperiod (June and August). The oldest emus tended to start the breeding season later than the youngest. The rates of EPF observed may indicate that the earlier the P2 (or peak production) value is, the lower the potential for egg production in emus was. Reproductive groups formed by only one couple of emus reproduced for the shortest intervals, and presented better breeding performances than colonies of emus, regardless of age.

\section{ACKNOWLEDGMENT}

We acknowledge financial support from Zooloja ${ }^{\circledR}$ and other donors, the graduate scholarship for the first author from Coordenação de Aperfeiçoamento de Pessoal de Nível Superior - CAPES, the mathematical models by PhD. João Pedro de Barros Reicao Cordido, the veterinary services by Domingos S. S. M. Smiderle, and the help translating the manuscript by Tradulab Instituto Federal do Espítio Santo - Guarapari Campus.

\section{REFERENCES}

AGMRC, Agricultural marketing resource center. A national information resource for value-added agriculture. Ames: Iowa State University, 2018. Available in: https://www.agmrc.org/commoditiesproducts/livestock/ostrich-and-emu-53585 Accessed in: 5 Aug. 2020.

BLACHE, R.T.; TALBOT, M.A.; BLACKBERRY, K.M.; WILLIAMS, G.B.; MARTIN, P.J. Photoperiodic control of the concentration of luteinizing hormone, prolactin and testosterone in the male emu (Dromaius novaehollandiae), a bird that breeds on short days. $J$. Neuroendocrinol., v.13, p.998-1010, 2001. 
CORDIDO, J.P.B.R. Eficiências nutricionais máximas e mínimas em povoamentos de eucalipto. 2019. 86f. Tese (Doutorado) - Universidade Federal de Viçosa, Viçosa, MG.

DZIALOWSKI, E.M.; SOTHERLAND, P.R Maternal effects of egg size on emu (Dromaius novaehollandiae) egg composition and hatchling phenotype. J. Exp. Biol., v.207, p.597-606, 2004.

GOONEWARDENE, L.A.; WANG, Z.; OKINE, E. et al. Comparative growth characteristics of emus (Dromaius novaehollandiae). J. Appl. Poult. Res., v.12, p.27-31, 2003.

IPEK, A.; SAHAN, S. Effect of breeder age and breeding season on egg production and incubation in farmed ostriches. Br. Poult. Sci., v.45, p.643-647, 2004.

LABAQUE, M.C.; MARTELLA, M.B.; MAESTRI, D.M.; HOYOS, L.; NAVARRO, J.L. Effect of age and body weight of greater Rhea (Rhea americana) females on egg number, size and composition. Br.Poult. Sci., v.51, p.838-846, 2010.

MALECKI, I.A.; MARTIN, G.B. Fertile period and clutch size in the emu (Dromaius novaehollandiae). Emu, v.102, p.165-170, 2002.

PATODKAR, V.R.; RAHANE, S.D.; SHEJAL, M.A.; BELHEKAR, D.R. Behavior of emu bird (Dromaius novaehollandiae). Vet. World, v.2, p.439-440, 2009.

POBLETE, P.C.; MOUSTACAS, V.S.; OLIVEIRA, C.H. et al. Atividade folicular ovariana em avestruz (Struthio camelus) avaliada por ultrassonografia e sua relação com fotoperíodo e postura. Arq. Bras. Med. Vet. Zootec., v.65, p.1573-1576, 2013.
ROSTAGNO, H.S.; ALBINO, L.F.T.; DONZELE, J.L. et al. Tabelas brasileiras para aves e suínos. Composição de alimentos e exigências nutricionais. 3.ed. Vicosa: UFV, 2011. 252p.

SAFAEIAN, R.; HOWARTH, G.S.; LAWRANCE, I.C.; TRINDER, D.; MASHTOUB S. Emu Oil reduces disease severity in amousemodel of chronic ulcerative colitis. Scand. J. Gastroenterol., v.54, p.273-280, 2019.

SALES, J. The emu (Dromaius novaehollandiae): a review of its biology and comercial products. Avian Poult. Biol. Rev., v.18, p.1-20, 2007.

SENTHILKUMAR, P.; JAGATHEESAN, R.P.N.; ANANDH, A.M.; RAJARAJAN, G.; LURTHUREETHA, G. Production performances and egg characteristics of emu (Dromaius novaehollandiae) birds. Indian J. Anim. Res., v.48, p.78-82, 2014.

SCHEIDELER, S.E.; SELL, J.L. Nutrition guidelines for ostriches and emus. Iowa: State University Extension, 1997.

SILVA, G.C.O; GUIMARÃES, M.A.B.V. Reprodução de avestruzes: uma revisão da fisiologia e do comportamento. Rev. Bras. Reprod. Anim., v.32, p.251-255, 2008.

SZCZERBIŃSKA, D.; MAJEWSKA, D.; TARASEWICZ, Z. et al. Emu (Dromaius Novaehollandiae) laying performance and egg quality during a ten-year reproductive performance period. Electr. J. Pol. Agric. Univ., v.17, p 8, 2014.

VAN SCHALKWYK, S.J.; CLOETE, S.W.P.; KOCK, J.A. Repeatability and phenotypic correlations for body weight and reproduction in commercial ostrich breeding pairs. Br. Poult. Sci., v.37, p.953-962, 1996. 